\title{
Sustainability of Family-Owned Businesses in the Willowvale Industrial Area of Harare, Zimbabwe
}

\author{
Moses Chundu ${ }^{1 *}$, Julia Njobo ${ }^{2}$, Jeffrey Kurebwa ${ }^{2,3}$ \\ ${ }^{1}$ Faculty of Business Management Sciences and Economics, University of Zimbabwe, Harare, Zimbabwe \\ ${ }^{2}$ Africa Leadership and Management Academy (ALMA), Harare, Zimbabwe \\ ${ }^{3}$ Department of Peace and Governance, Faculty of Humanities and Social Science, Bindura University of Science Education, \\ Bindura, Zimbabwe \\ Email: ^mtgjcc@gmail.com, julia.njobo42@gmail.com, jeffkurebwa2015@gmail.com
}

How to cite this paper: Chundu, M., Njobo, J., \& Kurebwa, J. (2021). Sustainability of Family-Owned Businesses in the Willowvale Industrial Area of Harare, Zimbabwe. American Journal of Industrial and Business Management, 11, 461-480. https://doi.org/10.4236/ajibm.2021.115029

Received: April 14, 2021

Accepted: May 18, 2021

Published: May 21, 2021

Copyright ( 2021 by author(s) and Scientific Research Publishing Inc. This work is licensed under the Creative Commons Attribution International License (CC BY 4.0).

http://creativecommons.org/licenses/by/4.0/

(c) (i) Open Access

\begin{abstract}
The study sought to evaluate the sustainability of family-owned businesses which were situated in Willowvale industrial area of Harare. The study emanated from the fact that family-owned businesses were experiencing high failure rates. The research explored challenges faced by family-owned businesses, investigated the coping strategies which they adopted, evaluated the link between success factors and sustainability and identified forms of government assistance. Mixed research approaches were adopted. The study found that the family-owned businesses faced a myriad of challenges chief among them shortage of capital, adverse economic environment and stiff competition. The companies lacked in appreciating the role of innovation, information technology, efficiency and quality in enhancing sustainability of their businesses. Coping mechanisms involve reorganising their operations, balancing costs, having family support and mixing entrepreneurship with emotion. There was a weak link between corporate governance, succession planning and management practices with sustainability of family-owned businesses in Willowvale. However, there was a strong link between sustainable competitive advantages and sustainability of these organisations.
\end{abstract}

\section{Keywords}

Corporate Governance, Firm Competitiveness, Small Firm Growth, Succession Planning

\section{Introduction and Background}

Family-owned businesses take different shapes and forms, with consensus on the 
generic definition that a family-owned business is any business in which the family members are affected by the business decisions. According to Sharma et al. (1997: p. 3), "a family business is a business governed or managed on a sustainable, potentially cross-generational basis to shape and perhaps pursue the formal or implicit vision of the company held by members of the same family or a small number of families". Family firms dominate most countries' economic landscape and are a vital element of the private sector throughout the world (European Commission, 2009). It is not surprising that there is a growing scholarship on this form of enterprise both domestically and internationally (Chrisman et al., 2005; Astrachan \& Shanker, 2003). Globally, family-owned businesses constitute about 80 percent to 98 percent of all enterprises employing between 50 percent and 75 percent of the world's working population (Poza \& Daugherty, 2013). However, their biggest challenge is to sustain sales growth and profit hence competitiveness. "Family business sustainability is the ability to ensure the persistence of the family over time, combining the continuity of the family myth with social responsibility and creating a community of values and intentions" (Schillaci et al., 2013). "Sustainability is a compelling strategy to increase business sales, investment and financial assistance, talent, workforce diversity and productivity, company visibility, and goodwill" (Dyllick \& Muff, 2016: p. 6).

In the USA, for instance, approximately 30 percent of family-owned firms survive to the second generation of family members with 12 percent surviving to the third generation and a mere 3 percent to the fourth generation and beyond (Byrd \& Megginson, 2013). However, Miller and Le Breton-Miller (2006), argue that families founded multi-national companies such as Michelin, Armani, Walmart, Home Depot, and E-Bay as very small enterprises and families still have control today. They managed to grow into world-class businesses. Notwithstanding the support measures put in place, their longevity and sustainability through generations remain a significant cause for concern for all stakeholders.

According to the Lobbying Africa (2019) cited in Sandada and Mangwandi (2015), the causes of business failure in Africa include: being out of touch with customers, poor decision making, inability to pinpoint profitable business model, inadequate market research, lack of proper planning and absence of accountability among others (Taneja et al., 2016). Challenges typified with family business are the concentration of ownership, control, and critical managerial positions among family members. This results in poor management practices, lack of succession planning, lack of innovative methods, issues of governance, high taxes, harsh economic and financial problems, and top global competition (Sandada \& Mangwandi, 2015). However, family firms come with their own set of unique advantages which include being managed by owners who have an unrelenting and standpoint that is generationally inherited. They also usually operate more informally than other companies do. Their way of business also rests on relationships, allowing them to sustain lasting relationships with their key stakeholders (Hoffmire, 2014).

According to the Family Enterprise Survey United States of America (USA), 
(2011), the United States has about 5.5 million family businesses contributing 57 percent of GDP and employing 63 percent of the workforce (Tharawat Magazine, 2014) and 78 percent of all new jobs (Astrachan \& Schanker, 2003). A substantial number of American companies that have family-owned business origins are in existence today and have grown and spread across continents. These include Nike, Oracle, Facebook and Walmart, to name a few. The 2014 Family-Owned Business Institute survey with a sample of 690 family businesses found a typical age of a family business in West Michigan to be 50 years. Eleven per cent of the businesses were 100 years and over with an impeccable history of social responsibility and job creation (Family Owned Business Institute, 2019).

A worrying trend in Zimbabwe is the failure of these family businesses to survive beyond the death or even mere incapacitation of the founding owners. The consequences of such unfortunate development, which includes loss of employment, is problem enough to warrant an investigation into their sustainability. Thus, this study aims to explore and evaluate various factors that affect the viability of family-owned firms. The study also seeks to contribute to understanding how family-owned businesses are copying in the harsh economic environment. The findings will help family-owned businesses in Zimbabwe gain insight into how they can best formulate and implement strategies to enhance sustainable competitive advantage. Further, the study will add to the existing body of literature on family businesses and provide information for further scholarly research on the success factors of family-owned business sustainability.

This study, therefore, explores the sustainability of family-owned businesses with specific reference to the Willowvale Industrial Area in Harare, Zimbabwe. The following are the specific objectives that guided the study:

1) To identify the challenges faced by a family-owned business in Zimbabwe.

2) To analyse the coping strategies of family-owned businesses during the harsh economic environment.

3) To identify the role of the government in ensuring the sustainability of family-owned businesses in Zimbabwe.

4) To establish the relationship between the demographic characteristics of family business managers, business characteristics, and business sustainability.

5) To identify the initiatives that can be employed to ensure family-owned business sustainability.

The rest of the paper is organised as follows. Section 2 gives a brief overview of family-owned businesses in Zimbabwe followed by the review of literature. Section 4 gives the methodological background to the study, followed by presentation and discussion of estimation results. The paper concludes by giving a summary and policy implications of the study.

\section{Overview of the Zimbabwe Family Business Sector}

Most (80\%) of businesses in Zimbabwe are family-owned and are predominantly small to medium-sized, thriving under the guidance of the founding member (Nyoni, 2019). The SME sector has gained a substantial foothold of the Zim- 
babwean economy where it employs 60 percent of the workforce and contributes an estimated 50 percent of the country's GDP, creating scope for relevant authorities to give attention to the sector (Government of Zimbabwe, 2015). The sector also continues to complement large firms' production of goods and services in the face of declining foreign direct investment and liquidity crisis in Zimbabwe. The FinScope MSME Survey (2012) revealed that 2.8 million business owners, comprising different business types, employed 2.9 million people. The rapid growth in these enterprises automatically triggers the need to provide a specific kind of corporate governance that fits family-owned businesses. It represents a significant tissue of the Zimbabwean economy. The rapid growth in family businesses in the country is attributable to the transformation that is happening in traditionally large firms who have been downsizing and pushing the new unemployed into the informal SMEs sector.

Zimbabwe has its share of successful companies that started as family businesses transforming over the years to become giant corporates. For instance, the Meikles family business empire is the oldest in Zimbabwe to have successfully grown to become a listed counter on the Zimbabwe Stock Exchange. Other examples of the companies that started as family-run businesses include Econet Wireless Zimbabwe, Nyaradzo Funeral Services, Moonlight Funeral Services, and Peace Security Company, to name but just a few. However, for most familyowned businesses, their longevity and sustainability through generations remain a significant cause for concern.

Through the blueprint document, Transitional Stabilisation Programme Reforms Agenda (October 2018 to December 2020), the Zimbabwean Government acknowledges the role of business enterprise in promoting growth and development in the economy, hence the measures to support and unlock the potential of the SMEs. To this end, the government put measures to support and boost the performance of small and medium enterprises, under which the family businesses fall for the benefit of the economy through a dedicated Ministry of Small and Medium Enterprises and Cooperative Development.

\section{Literature Review}

\subsection{Theoretical Framework}

An attempt to fathom the complexities of family businesses which came to the forefront in the early 2000s, spawned several studies integrating concepts from organisational, business management and family systems theory. Four theories are mostly used in family research to explain the functionality and characteristics of family firms. These are Resource-based View, Agency theory, Stewardship theory and Social Capital theory (Sandada \& Mangwandi, 2015). However, Sandada and Mangwandi (2015) posits that, although these four theories give an insight into family business features/characteristics, the systems theory framework is most commonly used by family business intellectuals and consultants to analyse and evaluate family firms. Poza and Daugherty (2013) also argue that the 
systems theory framework has much to offer in explaining how the three subsystems of family business interrelate to create family business dynamics, thus adding to the body of knowledge for a deeper understanding of family businesses. However, Sandada and Mangwandi (2015) further accentuates that when comparing family businesses and non-family businesses in terms of performance and longevity, all the other theories become relevant and applicable although to varying extents as these theories underline the distinctiveness of family firms amongst organisational firms.

\subsubsection{Systems Theory}

Systems theory models family business as being made up of three complex interdependent subsystems of family, management and ownership with each subsystem separated from the other and from the external operating ecosystem whilst also striving to maintain these boundaries (Poza, 2010). Thus, the theory demonstrates how the success of a firm is based on the balancing of entrepreneurial, managerial and ownership goals (Koiranen, 2003). The art of balancing these there requires versatility on the part of management to keep abreast with a diverse and an evolving operating environment (Poza, 2010).

\subsubsection{Resource-Based View (RBV) Theory}

RBV theory focuses on resources as the most fundamental unit of analysis in the firm. A firm's competitiveness derives from a set of specific, distinctive, immoveable, inimitable and sometimes intangible resources and the ability of a firm's management in combining these resources (Penrose, 1959). Habbershon et al. (2003), suggest that a firm's resources can be divided into four categories namely, physical, human, organisation and process capital resources. These resources must possess four characteristics to generate a competitive advantage. Resources have to be valuable, and they need to be rare/unique only available to one firm, thirdly they must be inimitable and lastly non-substitutable. Unless resources exhibit these features, they cannot be leveraged to enhance firm competitiveness and sustainability. Thus, the source of competitive advantage, and therefore sustainability, are these resources when combined with capable management.

\subsubsection{Agency Theory}

The agency theory focuses on the problems that arise in an organisation where there is separation of owners (principal) and managers (agent). This theory prescribes the governance framework necessary to control the agents' action. It is based on divergent interests, opportunistic behaviour and asymmetric information (Greenwood, 2003). It deals with the conflict of interest between a representative and the principal who delegates work to an agent. However, where no conflict of interest exists, there are no agency costs that arise. According to Greenwood (2003), the agency theory is based on two assumptions: first that the interests of principals and agents often (always) diverge and second that indi- 
viduals (principals and agents) seek to advance their interests (usually monetary) that link the agent's compensation to measurable attainment of the principal's goals.

High trust and shared values among families lower agency costs in family firms and enhance firm competitiveness, though these costs tend to rise in family firms with conflicts and competing goals and values (Chrisman et al., 2005). Schulze et al. (2003), use the agency theory to understand the dynamics of family firms better and in doing so incorporates the notion of "altruism" which is the cornerstone value in family firms, though making it a challenge to effectively monitor family members working in the firm.

\subsubsection{Stewardship Theory}

The limitations of the agency theory have led to the consideration of other complementary theories to explore the family firm's performance and longevity. The stewardship theory is one such theory which family business researchers (Westhead \& Howorth, 2006; Corbetta \& Salvato, 2004) have explored. The theory views people as collective self-actualisers seeking to maximise personal utility through organisational achievement. Founders cannot draw a line between themselves and their enterprises, viewing the firm as an extension of themselves, hence connected to their being (Poza, 2010). Thus, the stewardship theory provides greater insight into ownership and management of family businesses to the extent founders fail to separate themselves from the business, hence are bound to act as good stewards of the family enterprise (Greenwood, 2003).

\subsection{Empirical Literature Review}

Sustainability is a complex concept that is highly debatable in literature, requiring specificity in its use to avoid ambiguity. Oudah et al. (2018: p. 7) noted the "significant contribution of strategic planning to the success and long-term survival of family businesses. Strategic planning both establishes the business's scope and long-term goals and adopts resources and competencies in changing environments to achieve the required scope and goals". They further note inter and cross-generational variations in aspirations of management in pursuit of strategic goals. Al-Akra and Hutchinson (2013: p. 14) argue that "family-owned businesses do inadequate planning, and in some cases, the planning does not exist at all because of lack of leadership".

Access to capital is key to longevity and sustainability of family-owned enterprises. According to Bozas (2011), family-owned businesses tend to have poor financial management, and this is a disadvantage in the sustainability of the business. A research conducted by Mlobeli (2018) in Durban, KwaZulu Natal, shows that family-owned businesses have difficulties in acquiring finance from formal institutions because the banks avoid risk associated with especially informal SMEs. However, due to poor financial management, these businesses fail to acquire capital injections to which cash is the oxygen of all businesses.

Leadership plays a vital role in planning in a family-owned business. The re- 
duced level of planning found in the most family-owned businesses leads to fewer enterprises not being able to have a real vision for the future generations. It was also discovered that management did not have a vision for the business operation, and the businesses were operating purely on a reactive basis. It was also discovered that where the management meetings did discuss the future, this process was informal, and there were no documents involved. The focus was often on instant issues rather than on continuing issues. The business ended up with no fundamental goals or target to work towards meeting, and this is a factor that affects family-owned business (Al-Akra \& Hutchinson, 2013). Al-Akra and Hutchinson (2013) further argue that family-owned businesses are unable to treat employees in a way that would make them valuable in the process compromising staff efficiency and morale in the workplace and ultimately leading to unhappy customers.

Oudah et al. (2018) argue that family business values should be successfully transferred to and embedded in the next generation as they are key determinants of longevity in family-owned enterprises. However, Tàpies and Moya (2012) found that many family-owned businesses lack quality and hardworking members, which are the critical success factor towards the sustainability of familyowned businesses. According to Brink (2017), family-owned businesses operate in small geographic areas and often turn a blind eye to Information Technology, or are less likely to have in-house professionals, which serves as a deterrent to adapt to technology. It is vitally essential that family-owned businesses adapt to technology because, in the current digital age, everything occurs online and turning a blind eye on innovation will inevitably lead to business failure.

Succession planning is deficient in most family-owned enterprises with the result that failure is almost imminent. The effect of lack of succession planning is magnified when the founder dies in sudden death. The infights over the estate of the deceased that ensues usually leave the business vulnerable and continuity at stake (Oudah et al., 2018). Bryman et al. (2015) noted that external factors are the outside influence that can impact on a business. These factors are essential in business because they can influence the capability of the business to accomplish its strategic goals and objectives. According to an article published by the Piraeus Traders Association (2009), family businesses have higher resistance toward the impacts of the financial crises due to the unique family ties that can help them overcome problems with minimal losses. Firms run by founders have less incentive to over-invest in risky projects, thus reducing the chances of success (Zhou, 2012).

\subsection{Conceptual Framework}

In order to empirically test the influence of the sustainable competitive advantage the conceptual framework used by Sandada and Mangwandi (2015) was adopted in which succession planning, sustainable competitive advantage, corporate governance and management practices are said to influence long term 
sustainability of family-owned firms as shown in Figure 1. The envisaged framework is grounded on the agency theory, systems theory, resource-based theory and the stewardship theory. Business sustainability as the dependant variable is measured subjectively in this framework.

Figure 1 depicts this conceptualised research model as adopted from Sandada and Mangwandi (2015). The relationships hypothesised between the research constructs are discussed hereafter. Cloutier et al. (2015) argue that maintaining a sustainable competitiveness advantage requires a continuous focus on the four universal pillars of competitiveness, that is, competency, quality, innovation, and receptivity to customers and to develop unique capabilities that lead to higher performance.

There are various definitions for succession planning as given by various authors. The process involves transfer and development of implicit knowledge to members of the family likely to take over the leadership of the family business in the future (Miller \& Le Breton-Miller, 2006). It is also defined by Ward (1997) as the procedure of preparing to relinquish control of the business to the next generation in a way that is at least disruptive to the business operation and values. At least five years before retirement, showing that succession planning is a process and not an event, it encompasses deciding how and when management, ownership and control of the business will be transferred to succeeding owners ( $\mathrm{Si}$ komwe et al., 2012).

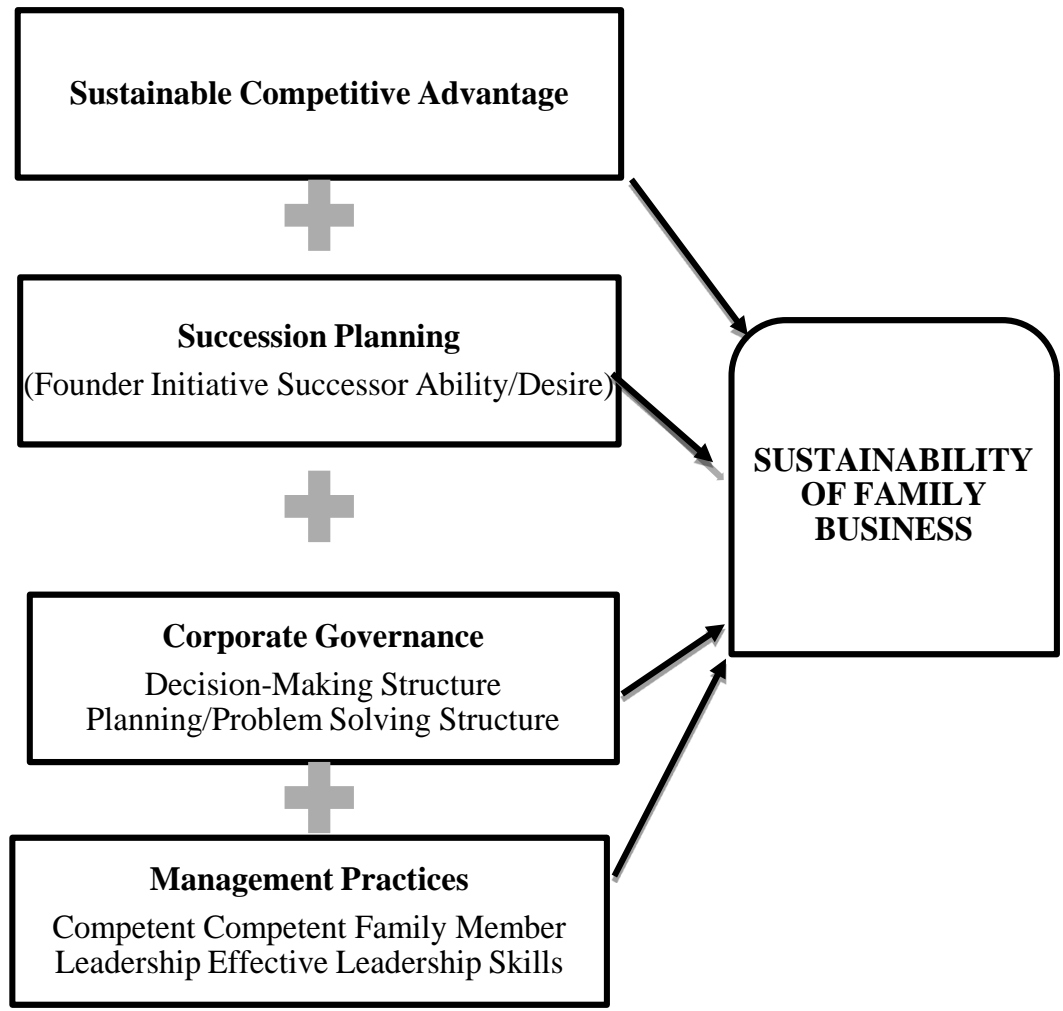

Figure 1. Conceptual framework of sustainability of family businesses. Source: Adapted from Sandada and Mangwandi (2015). 
Corporate governance has recently risen as one of the most important concepts developed by business and financial experts to ensure that corporate organisations not only survive but also operate in the best interest of all stakeholders (Jayashree, 2006). A sound system of corporate governance ensures that directors and managers of enterprises are guided by a framework of accountability and transparency in carrying out their duties. Jayashree (2006) describes corporate governance as a way of life and not a set of rules. The corporate governance concept is anchored in the framework of two theories, mainly the Agency theory and the Stewardship theory (Omolade \& Tony, 2014). Agency theory presents governance as a contract between directors and the shareholder with directors and managers seeking to maximise their utility at the expense of the stockholders. Subsequently, this gives rise to agency costs in a bid for the shareholders to ensure adequate disclosure and appropriate checks and balances (Omolade \& Tony, 2014). The stewardship theory on the other hand is based on the original and legal company definition in which directors have an obligation to the shareholders to act in the best interest of the company at all times and not in their interest. Corporate governance, therefore, hinges on complete transparency, integrity and accountability of management (Jayashree, 2006).

Management/ managerial skills can be defined as "the ability to make business decisions and lead subordinates within a company. Three most common skills include social skills (ability to interact and motivate), technical skills (knowledge and proficiency in the trade), conceptual skills (ability to understand concepts, develop ideas and implement strategies)" (Gichuhi et al., 2014: p. 6). It is, therefore, very essential for managers, especially in family businesses, to master management skills which are critical to the success of their management career.

\section{Methodology}

\subsection{Research Design}

A case study is the most appropriate model to examine the organizational realities in a real-life setting with an in-depth exploration of a few cases (Robson, 2002). The Willowvale industrial area comprises businesses involved in diverse activities such as manufacturing, retail, services, and agents, among others. A mixed-methods approach integrating quantitative and qualitative research was used to provide a better understanding of the research problem than either of each alone (Saunders et al., 2012). This was the most applicable for the study's objectives, which aim to establish people's opinions regarding the issues affecting family-owned businesses given the considerable stakeholder diversity within the heterogeneous small family firms.

\subsection{Study Sample}

The targeted population was a case study of Willowvale Industrial Area family-owned businesses in the City of Harare. The key informants in the study are people with the information or the know-how of what is being investigated. The 
informants included are family-owned business owners, managers, and administrators. These people were selected because they are in a better position to know every aspect of the business since they are involved in the day-to-day operations. They are the owners of business or part of the business owned generation. A sample of 133 was derived from a population of 200 family businesses in the Willowvale industrial area using the Yamane method. The random sampling and purposive sampling techniques were employed for the quantitative leg of this mixed-methods whilst purposive sampling was used for the qualitative research, which is useful to explore anthropological situations from an intuitive approach (Golafshani, 2003). The research covered family business operations from the end of 2015 to mid-2020, as this was where most businesses were affected by economic turmoil or hardships. During this period, many companies in Zimbabwe embraced the sustainable business model.

\subsection{Data Collection Procedures}

The study utilised both qualitative and quantitative data collection techniques to collect primary data. This included surveys, interviews, observations, and experiments (Yin, 2017). A questionnaire was administered to the sample, which consisted of proprietors, managers, and administrators of the family businesses. The study employed the interview guide for key informants to obtain detailed information about personal feelings, perceptions, and opinions allowing for clarification of ambiguities. One of the limitations for this method of data collection is the fact that a number of the potential participants were not keen on face-to-face interviews due to the prevailing COVID-19 pandemic yet virtual interviews were limited by poor connectivity infrastructure. In order to improve the validity and reliability of the research instruments, the triangulation method was applied by combining primary methods and secondary sources (Saunders, Lewis, \& Thornhill, 2012). The participants were allowed to decide to participate in the study voluntarily to ensure data were offered freely and frankly. Participants were assured of the utmost confidentiality and anonymity to protect the privacy and also for retention of the validity of the research. The participants were also advised of their right to refuse to answer any questions or to participate in the study.

\section{Presentation and Discussion of Results}

\subsection{Demographic Profiles}

According to Baruch and Holtom (2008), a response rate of at least 50 percent on self-administered researches is acceptable, and therefore the research aggregate response rate of $72.2 \%$ was adequate for empirical analysis in this research. Approximately $52.08 \%$ of the total participants were female, while male participants occupied the remaining $47.92 \%$, hence the absence of gender bias in the sample. On business ownership, $56.25 \%$ of the proprietors were male with females constituting $43.75 \%$. This is an indication that the lobbying for women to 
participate more and more in business was yielding positive results.

On age profiles, $14.6 \%$ of participants were below the 30 years age group with approximately $33.3 \%$ being the dominant 30 - 40 years age group. The age groups between 41 - 50 and 51 - 60 each scored $18.8 \%$ of the total participants. Those research participants who were above 60 constituted $14.6 \%$ implying a fair representation of all age groups. It also implied that people retiring were also venturing into family-owned.

The ability to understand questions raised from the research instruments and the quality of the data generated depended much on the level of education of the participants. Approximately, 29.2\% of the participants had secondary education as their highest level of education while the same score was achieved for those whose level of education was undergraduate degrees. Approximately 25 percent of the total participants held diplomas, while the remaining $16.8 \%$ of the total participants had post-graduate degrees. A total of $71.1 \%$ of the participants had at least diplomas as their highest level of education. This high level of education meant better skills to successfully run family businesses.

In terms of management structure, $52.1 \%$ of the total participants held the positions of manager for the family-owned businesses which participated in the study. This frequency was explained by the fact that some of the owners of the businesses were full-time politicians, whilst others had full-time jobs with other big companies. Business administrators who participated in the study constituted 25 percent of the total participants. The majority of administrators were appointed based on family attachment to manage general office activities and the handling of cash. The remaining $22.5 \%$ of the total participants related to the proprietors who were owner-managers of their companies.

\subsection{Research Findings}

The following are the presentations and discussion of findings of the study arranged by study objective.

\section{Challenges faced by a family-owned business}

These hampered their ability to sustain their operations. Eight challenges were tested to establish if they affected the operations of family-owned businesses operating in the Willowvale industrial area of Harare and the results are summarized in Table 1. Combining moderate and severe affirmation, results show that approximately 75 percent viewed their businesses as having been severely and moderately affected by a shortage of capital as family-owned businesses needed the capital which they could not access at the time to sustain their businesses. Managing directors of family-owned businesses also revealed that they needed operating capital to venture into more successful projects, but they did not manage to achieve this because there were no credit lines in the country to cater for them.

Approximately 80 percent believed that their operations had not been failed by lack of leadership issues indicating that many of their companies had been led by qualified business people who would always put down contingent measures 
Table 1. Challenges faced family-owned businesses.

\begin{tabular}{ccccc}
\hline & Not at all & Insignificantly & Moderately & Severely \\
\cline { 2 - 5 } & Row N percent & Row N percent & Row N percent & Row N percent \\
\hline Lack of capital & $10.4 \%$ & $14.6 \%$ & $31.2 \%$ & $43.8 \%$ \\
Leadership issues & $35.4 \%$ & $45.8 \%$ & $6.2 \%$ & $12.5 \%$ \\
Lack of skills & $8.3 \%$ & $18.8 \%$ & $31.2 \%$ & $41.7 \%$ \\
Legal issues & $31.2 \%$ & $43.8 \%$ & $16.7 \%$ & $8.3 \%$ \\
Increased competition & $16.7 \%$ & $25.0 \%$ & $20.8 \%$ & $37.5 \%$ \\
Economic environment & $12.5 \%$ & $16.7 \%$ & $33.3 \%$ & $37.5 \%$ \\
Technological issues & $31.2 \%$ & $41.7 \%$ & $12.5 \%$ & $14.6 \%$ \\
Social and environmental issues & $37.5 \%$ & $22.9 \%$ & $16.7 \%$ & $22.9 \%$ \\
\hline
\end{tabular}

Source: authors' own calculation.

to ensure they remain operational against the adverse market-related factors. This is contrary to findings by Al-Akra and Hutchinson (2013) who posited that family business leadership often lacked adequate planning and operated without a vision. The participants, however, observed that they operated without adequate human resources skills which were necessary to sustain their operations as $41.7 \%$ and $31.2 \%$ indicated that they were severely and moderately affected by this challenge respectively. Many of their procedures are short cuts while they usually operate without functions like accounting. This was in convergence with findings by Bozas (2011) who posited that family-owned businesses ignored financial management skills desirable to sustain their operations, resulting in misappropriation of business funds.

Participants, through both interviews and questionnaires, believed that the economic environment, which was prevailing in Zimbabwe at the time of doing this study affected their operations adversely. They perceived that much of the challenges which they faced emanated from the adverse economic environment which had affected companies in Zimbabwe for more than a decade at the time of doing this study. Approximately, $70.8 \%$ were affected by the adverse economic environment. This is also consistent with findings by Lekhanya (2016) who established that family-owned and SMEs operating in harsh economic environments had high levels of mortality. High levels of competition were also a challenge with $58.3 \%$ of the participants severely and moderately affected. They also revealed that many of the SME's were operating in the informal markets and hence, those properly registered companies faced competition from unregistered dealers who supplied cheap imports which were not durable. Surprisingly, the participants did not believe that they were significantly affected by legal issues, technological issues or social and environmental issues at the time of doing this study.

Coping strategies of family-owned businesses during the harsh economic environment. 
A combined $60.4 \%$ of the respondents claimed to have reorganized operations in their family-owned businesses in light of many challenges which they faced. Approximately, 56.2\% of the total participants strongly agreed that they balanced emotions with entrepreneurship to see their businesses sustaining. Seventy seven percent resorted to receiving support from their families to ensure that they remained afloat. This was mostly driven by the desire to ensure that their families would prosper, resulting in them working harder than they would do while working for other people. These findings were in agreement with those of Zhou et al. (2012), who posited that family members had a burning desire to see their families being successful. The study also found out that the majority of participants (70.8 percent) were self-assessed and criticised themselves whenever possible, and this helped them to cope in their businesses. This self-introspection was vital for them to sustain their operations in the face of a myriad of challenges which include cash and foreign currency shortages, high-interest rates and the latest COVID-19 pandemic among other hurdles.

Role of the government in ensuring the sustainability of family-owned businesses

The findings on the areas of provision of cheaper loans, provision of subsidies and training indicated that the government could do more to enable the businesses to sustain their operations (see Table 2).

Lack of capitalisation contributed to family-owned businesses remaining small. This is demonstrated by a combined $60.4 \%$ of the participants who disagreed that the government helped family-owned businesses to access loans at low-interest rates. In the same vein a combined $58.8 \%$ confessed to not receiving any subsidies from government. These findings also converged with those of Oudah et al. (2018), who concluded that family-owned businesses usually operate without much capital needed for long term sustainability. A study by Mlobeli (2018) in Durban, KwaZulu Natal also attested to family-owned businesses having difficulties accessing finance from formal institutions who consider them too risk.

Table 2. Coping strategies.

\begin{tabular}{cccccc}
\hline & $\begin{array}{c}\text { Strongly } \\
\text { agree }\end{array}$ & Agree & Neutral & Disagree & $\begin{array}{c}\text { Strongly } \\
\text { disagree }\end{array}$ \\
\cline { 2 - 5 } & $\begin{array}{c}\text { Row N } \\
\text { percent }\end{array}$ & $\begin{array}{c}\text { Row N } \\
\text { percent }\end{array}$ & $\begin{array}{c}\text { Row N } \\
\text { percent }\end{array}$ & $\begin{array}{c}\text { Row N } \\
\text { percent }\end{array}$ & $\begin{array}{c}\text { Row N } \\
\text { percent }\end{array}$ \\
\hline $\begin{array}{c}\text { Reorganisation } \\
\begin{array}{c}\text { Balancing emotions with } \\
\text { entrepreneurship }\end{array}\end{array}$ & $20.8 \%$ & $39.6 \%$ & $16.7 \%$ & $14.6 \%$ & $8.3 \%$ \\
$\begin{array}{c}\text { Family support } \\
\text { Self-assessment and } \\
\text { self-criticism }\end{array}$ & $52.1 \%$ & $25.0 \%$ & $4.2 \%$ & $12.5 \%$ & $6.2 \%$ \\
\hline
\end{tabular}

Source: authors' own calculation from survey data. 
The results also indicated that there was no training support based on 25 percent who disagreed and the other $31.2 \%$ who strongly disagreed to receiving it. Regarding the reduction of the legal burden, there were balanced views. Those who agreed were appreciating the fact that the laws were promoting the indigenous Zimbabweans to start businesses of their own while being private companies, they inherently had lesser legal burdens. Those who disagreed and strongly disagreed believed that the government could have gone an extra mile in reducing tax-related costs.

Relationship between the demographic characteristics of family business managers, business characteristics and business sustainability

One of the purposes of this research was to investigate the demographic characteristics of family-owned businesses which operated in the Willowvale industrial area at the time of doing this study and link them with the sustainability of their businesses. Some of the issues considered were the age of proprietors, the gender of proprietors, and the sectors which their organisations operate in. People of all ages, including those whose age group was below 30 and those who fell in the retiring age category, could start a business. Women proprietors were approximately 43 percent, indicating that everyone could start family-owned businesses. Majority of the companies were tiny as they employed below six employees. The bulk of the companies were agents of other businesses while some were in service provision. Political factors are those factors that regulate the extent to which a government may affect family-owned businesses.

The study affirmed that those family-owned businesses which had employed five or fewer employees at the time of doing this study constituted $43.75 \%$ of the total participants. The other $39.58 \%$ was occupied by companies which employed between 6 - 30 employees. These findings indicate that family-owned businesses were tiny while the nature of their businesses employed very few employees. An approximate $12.5 \%$ was occupied by the family-owned businesses which employed between 31 - 75 employees while those which employed more than 75 employees occupied the remaining 4.1 percent. The fact that few of the companies were in manufacturing implies that many of the companies were in sectors which were very low labor-intensive. These findings also indicate that all of the family-owned businesses which participated in this study could be classified in the categories of small to medium enterprises.

Initiatives that can be employed to ensure family-owned business sustainability.

The findings of the study show that $56.3 \%$ of the participants were of the view that the sustainability of their family-owned companies depended to a large extent on strategic management. They believed that the environment in Zimbabwe at the time of doing this study was unique, and hence it needed strategising while reviewing the plans regularly to assess their effectiveness as the environment was very turbulent. The findings of the study diverged with those of Al-Akra and Hutchinson (2013) who posited that family-owned businesses usually oper- 
ated with inadequate plans, vision and tended to have short term focus. An estimated $68.1 \%$ of participants believed that cost management was significantly valued by family-owned management to manage stiff competition. Businesses had no control over their revenues but cost management was something they could control. The desire to manage costs made managers work with minimal staff, eliminate other functions like finance, evade statutory costs like a value-added tax (VAT), import duties, pay as you earn (PAYE) and National Social Security Authority (NSSA).

In terms of innovativeness, $43.75 \%$ of the total participants believed that they were moderately active while the other 25 percent claimed that they were ineffective in being so. These findings indicate that the family-owned businesses were lacking in this vital aspect, which was critical in the administration of their businesses. The fact that they did not invest in information technology indicated that they did not know they lacked knowledge that information technology was a component which they required in terms of innovating their operations. According to Brink (2017), family-owned businesses tended to turn a blind eye on the fact that information technology and innovation would help them to save costs, generate more income and bring efficiency on their operations. A mere $18.8 \%$ of the participants believed their operations were active and effective in managing efficiency. Equally so, family-owned businesses were ineffective in terms of quality aspects of their operations and the products of their output. This, in the long run, had negative impact on sustainability.

On succession planning, the majority (62.5\%) of the family-owned businesses did not view succession planning as a valuable component which can sustain the business. The economic challenges in the market like shortage of foreign currency, liquidity crisis, high borrowing costs increased competition and the latest devastating effects COVID-19 pandemic affected participants to the point long term issues like succession ceased to be priority. This seems to support findings by Brink (2017) who concluded that proprietors of family-owned businesses might have skills; however, they would hardly impart them to those who will take over after their demise and this would in future affect their sustainability.

The companies had a mixed appreciation of good management practices like leadership and how it could also help them to achieve long term sustainability of their businesses with a $41.7 \%$ of the participants citing a remote link between the leadership of family businesses and sustainability. Related to leadership is the aspect of governance where a whopping $45.8 \%$ of the participants believed that corporate governance had a remote link with the sustainability of their family-owned companies with $35.4 \%$ citing no link at all.

\section{Conclusion and Policy Implications}

\subsection{Summary of Findings}

The findings indicated that family-owned businesses were significantly affected by adverse economic conditions, which were prevailing at the time of doing this 
study. Some of the challenges which they faced emanated from the high liquidity crisis, shortage of foreign currency and high borrowing costs at the time of doing this study which adversely affected their businesses. The findings regarding this objective were that family-owned businesses had reorganised their operations in the light of many challenges which they faced, mixed emotions and entrepreneurship and they received great support from their families to ensure that they remained afloat. They were mostly driven by the desire to ensure that their families would prosper, resulting in them working harder than they would do while working for other people. The findings on the areas of provision of cheaper loans, provision of subsidies and training indicated that the government could do more to enable the businesses to sustain their operations. People of all ages, including those whose age group was below 30 and those who fell in the retiring age category, could start a business. Women proprietors were approximately 43 percent, indicating that everyone could start family-owned businesses. Majority of the companies were tiny as they employed below six employees. The bulk of the companies were agents of other businesses while some were in service provision. The findings of the study show that participants were of the view that the sustainability of their family-owned companies had a secure link with strategic management.

On succession planning and corporate governance aspects, the majority of the family-owned businesses did not view succession planning as a valuable component which can sustain the business. The companies had a mixed appreciation of good management practices like leadership and how it could also help them to achieve long term sustainability of their businesses.

\subsection{Recommendations}

Given the importance of family-owned business to the country's economy, there is need for the Ministry of Finance and Economic Development through the Reserve Bank, financial institutions in the country and development partners to come up with tailor-made financing packages for the small family businesses in order to assist them to sustain their operations. The Ministry of Women Affairs, Small and Medium Enterprises should consider coming up with training programmes that enhance business knowledge for the small businesses, incorporating the use of technology and coping mechanisms in the wake of harsh economic environment and the COVID-19 pandemic. In support of the family-owned businesses in the country, the government through the Ministry of Women Affairs, Small and Medium Enterprises may also consider coming up with ways to recognise the family-owned businesses legally in Zimbabwe to give them an impetus to grow. The European Union legally recognises family businesses and have information and definition of a family business. This would ensure that there is a database for family businesses which could facilitate communication and understanding of the businesses.

The Ministry of Youth, Sport, Arts and Recreation needs to consider looking 
at ways to involve the youth in business since they are the future and also come up with financing packages that incentivise the youth to venture into business for the economic growth of the country. Family businesses should adopt new technologies in order for them to be competitive. Issues of succession and corporate governance should be seriously considered in order for businesses to continue to be sustainable. The businesses may also consider venturing into more long-term ventures in manufacturing which has very few participants rather than focusing on the agent business, which is already flooded.

\subsection{Areas for Further Research}

The prevailing COVID-19 pandemic posed the biggest challenge to data collection. Due to social distancing, some participants were not willing to have face to face interviews. Further, because of the ongoing COVID-19 lockdown, some of the businesses were closed, or they had a rotational arrangement, which made obtaining feedback difficult. Given the importance of this sector to the economy of the country, a countrywide research study would be important in order to identify the critical interventions that need to be implemented in order to harness the family business sector for the benefit of the economy.

\section{Conflicts of Interest}

The authors declare no conflicts of interest regarding the publication of this paper.

\section{References}

Al-Akra, M., \& Hutchinson, P. (2013). Family Firm Disclosure and Accounting Regulation Reform in the Middle East: The Case of Jordan. Research in Accounting Regulation, 25, 101-107. https://doi.org/10.1016/j.racreg.2012.11.003

Astrachan, J. H., \& Shanker, M. C. (2003). Family Businesses' Contribution to the US Economy: A Closer Look. Family Business Review, 16, 211-219. https://doi.org/10.1177/08944865030160030601

Baruch, Y., \& Holtom, B. C. (2008). Survey Response Rate Levels and Trends in Organizational Research. Human Relations, 61, 1139-1160. https://doi.org/10.1177/0018726708094863

Bozas, L. A. (2011). Key Success Factors for Small Businesses: Trading within the City of uMhlathuze. Doctoral Dissertation, Durban: University of KwaZulu-Natal.

Brink, A. (2017). Virtues, Principals, and Agents. In A. Sison, G. Beabout, \& I. Ferrero (Eds.), Handbook of Virtue Ethics in Business and Management. International Handbooks in Business Ethics (pp. 1003-1012). Dordrecht: Springer.

https://doi.org/10.1007/978-94-007-6510-8 100

Bryman, A. et al. (2015). Research Methodology: Business and Management (3rd ed.). Oxford: Oxford University Press.

Byrd, M. J., \& Megginson, L. C. (2013). Small Business Management: An Entrepreneur's Guidebook (7th ed., p. 35). New York: McGraw-Hill/Irwin.

Chrisman, J., Chua, J., \& Litz, R. (2005). Trends and Directions in the Development of a Strategic Management Theory of the Family Firm. Entrepreneurship Theory and Prac- 
tice, 29, 555-575. https://doi.org/10.1111/j.1540-6520.2005.00098.x

Cloutier, O., Felusiak, L., Hill, C., \& Pemberton-Jones, E. J. (2015). The Importance of Developing Strategies for Employee Retention. Journal of Leadership, Accountability and Ethics, 12, 119-129.

Corbetta, G., \& Salvato, C. (2004). Self-Serving or Self-Actualizing? Models of Man and Agency Costs in Different Types of Family Firms: A Commentary on "Comparing the Agency Costs of Family and Non-Family Firms: Conceptual Issues and Exploratory Evidence". Entrepreneurship Theory and Practice, 28, 355-362. https://doi.org/10.1111/j.1540-6520.2004.00050.x

Dyllick, T., \& Muff, K. (2016). Clarifying the Meaning of Sustainable Business: Introducing a Typology from Business-as-Usual to True Business Sustainability. Organization and Environment, 29, 156-174. https://doi.org/10.1177/1086026615575176

European Commission (2009). Overview of Family Business Relevant Issues: Research, Networks, Policy Measures and Existing Studies. Europe: European Commission, Directorate-General for Enterprise and Industry.

Family Owned Business Institute (2019). Family Owned Business Institute-Family Firm Facts. https://www.gvsu.edu/fobi/family-firm-facts-5.htm

FinScope MSME Survey (2012). Zimbabwe FinScope Survey. Harare: Finmark Trust.

Gichuhi, A ., Ruhiu, R. W., Ngugi, P. K., \& Waititu, G. A. (2014). Waititu Senior Lecturer. International Journal of Social Sciences and Entrepreneurship, 1, 474-485.

http://www.ijsse.orghttp://www.ijsse.org

Golafshani, N. (2003). Understanding Reliability and Validity in Qualitative Research. The Qualitative Report, 8, 19-29.

Government of Zimbabwe (2015). National Budget Statement. Harare, Zimbabwe.

Greenwood, R. (2003). Commentary on: "Toward a Theory of Agency and Altruism in Family Firms". Journal of Business Venturing, 18, 491-494.

https://doi.org/10.1016/S0883-9026(03)00056-9

Habbershon, T. G., Williams, M., \& MacMillan, I. C. (2003). A Unified Systems Perspective of Family Firm Performance. Journal of Business Venturing, 18, 451-465. https://doi.org/10.1016/S0883-9026(03)00053-3

Hoffmire, J. (2014). Understanding the Importance of Family Businesses. https://www.retirementplanblog.com/small-business/family-business/

Jayashree, S. (2006). Some Views on Corporate Governance. http://www.indianmba.com/Faculty Column/FC282/fc282.htm

Koiranen, M. (2003). Understanding the Contesting Ideologies of Family Business: Challenge for Leadership and Professional Services. Family Business Review, 16, 241-250. https://doi.org/10.1177/08944865030160040301

Lekhanya, L. M. (2016). Determinants of Survival and Growth of Small and Medium Enterprises in Rural KwaZulu-Natal. PhD Thesis, Cape Town: University of the Western Cape.

Miller, D., \& Le Breton-Miller, I. (2006). Family Governance and Firm Performance: Agency, Stewardship, and Capabilities. Family Business Review, 19, 73-87. https://doi.org/10.1111/j.1741-6248.2006.00063.x

Mlobeli, S. (2018). Factors Affecting Family-Owned Businesses in Durban, KwaZulu-Natal. Doctoral Dissertation, Durban: Durban University of Technology.

Nyoni, T. (2019) Factors Affecting Succession Planning in Small and Medium Enterprises (SMEs) in Zimbabwe: A Case Study of Harare (pp. 1-14). Munich Personal RePEc Archive, Harare: University of Zimbabwe. https://mpra.ub.uni-muenchen.de/91352/ 
Omolade, O., \& Tony, O. (2014). Effect of Corporate Governance on the Survival and Sustainability of Banks in Nigeria. American Journal of Engineering Research, 3, 73-83.

Oudah, M., Jabeen, F., \& Dixon, C. (2018) Determinants Linked to Family Business Sustainability in the UAE: An AHP Approach. Sustainability Switzerland, 10, 246-269.

https://doi.org/10.3390/su10010246

Penrose, E. T. (1959). The Theory of the Growth of the Firm. New York: Oxford University Press.

Piraeus Traders Association (2009). Family Business Have Greater Resistance toward the Impacts of Financial Crises.

Poza, E. J. (2010). Late Stage Entrepreneurial Activity: What Students Should Know about Family-Owned and Family-Controlled Companies. In A. Stewart, G. T. Lumpkin, \& J. A. Katz (Eds.), Entrepreneurship and Family Business (Advances in Entrepreneurship, Firm Emergence and Growth, Vol. 12) (pp. 359-366). Bingley, Emerald Group Publishing Limited. https://doi.org/10.1108/S1074-7540(2010)0000012020

Poza, E. J., \& Daugherty, M. S. (2013). Family Business. 4th ed. Mason OH, Cengage Learning.

Robson, C. (2002). Real World Research (2nd ed.). Oxford: Blackwell.

Sandada, M., \& Mangwandi, L. (2015). An Assessment of the Influence of Selected on the Performance of Small to Medium Sized Family Owned Businesses in the Zimbabwe Retail Sector. Acta Universitatis Danubius. Economica, 11, 5-16.

http://journals.univ-danubius.ro/index.php/oeconomica/article/view/2854/html

Saunders, M., Lewis, P., \& Thornhill, A. (2012). Research Methods for Business Students (6th ed.). London: Pearson Education Limited.

Schillaci, C. E., Romano, M., \& Nicotra, M. (2013). Family Business Foundations: Theoretical and Empirical Investigation. Journal of Innovation and Entrepreneurship, 2, Article No. 22. https://doi.org/10.1186/2192-5372-2-22

Schulze, W. S., Lubatkin, M. H., \& Dino, R. N. (2003). Toward a Theory of Agency and Altruism in Family Firms. Journal of Business Venturing, 18, 473-490.

https://doi.org/10.1016/S0883-9026(03)00054-5

Sharma, P., Chrisman, J. J., \& Chua, J. H. (1997). Strategic Management of the Family Business: Past Research and Future Challenges. Family Business Review, 10, 1-35. https://doi.org/10.1111/j.1741-6248.1997.00001.x

Sikomwe, S. et al. (2012). Critical Perspectives on Succession Planning in the Commuter Transport Sector in Zimbabwe. International Journal of Business and Social Science, 3, 230-241.

Taneja, S., Pryor, G., \& Hayek, M. (2016). Leaping Innovation Barriers to Small Business Longevity. Journal of Business Strategy, 37, 44-51. https://doi.org/10.1108/JBS-12-2014-0145

Tàpies, J., \& Moya, M. F. (2012). Values and Longevity in Family Business: Evidence from a Cross-Cultural Analysis (pp. 1-20). Working Paper WP866, Pamplona: IESE Business School, University of Navarra.

Tharawat Magazine (2014). The Economic Impact of Family Business: A Compilation of Facts. Tharawat Magazine, Issue 22, 1-12.

Ward, J. (1997). Growing the Family Business: Special Challenges and Best Practices. Family Business Review, 10, 323-337. https://doi.org/10.1111/j.1741-6248.1997.00323.x

Westhead, P., \& Howorth, C. (2006). Ownership and Management Issues Associated with Family Firm Performance and Company Objectives. Family Business Review, 19, 301-316. 
https://doi.org/10.1111/j.1741-6248.2006.00077.x

Yin, R. K. (2017). Case Study Research Design and Methods (5th ed.). Thousand Oaks, CA: Sage.

Zhou, H. (2012). Essay on Family Firms. PhD Thesis, Copenhagen: Copenhagen Business School.

Zhou, H., Wang, Y., \& He, F. (2012). Are Family Firms Better Performers during Financial Crisis: New Insights from the S\&P 500 Firms. Asian Finance Association (AsFA) 2013 Conference. 